\title{
ISOTOPE AND GEOCHEMICAL CHARACTERIZATION OF SURFACE AND SUBSURFACE WATERS IN THE SEMI-ARID SOKOTO BASIN, NIGERIA
}

\author{
S.M.A. Adelana ${ }^{1}$, P.I. Olasehinde ${ }^{1}$ and P. Vrbka ${ }^{2}$ \\ ${ }^{1}$ Department of Geology \& Mineral Sciences, University of Ilorin, \\ P.M.B. 1515, Ilorin, Kwara State, Nigeria. \\ ${ }^{2}$ Kaupstrasse 37, Germany (formerly Geology Institute, \\ Technical University Darmstadt, Germany).
}

\begin{abstract}
Stable isotopes and geochemical studies have been applied in the investigation of groundwater resources in Sokoto Basin, northwestern Nigeria. Generally, the characteristic hydrochemical classification in the study area is calcium-alkali-bicarbonate. Surface waters are characterized by alkali-calcium-bicarbonate while groundwater is of $\mathrm{Ca}-\mathrm{Mg}-\mathrm{HCO}_{3}$. The plot of $\delta^{18} O$ versus $\delta^{2} H$ shows that five isotopic groups can be distinguished. Group I-III is of groundwater origin while group $I V$ and $V$ represent surface water. A combination of the hydrochemical and isotope data $\left({ }^{14} \mathrm{C},{ }^{13} \mathrm{C}\right.$ and $\left.{ }^{3} \mathrm{H}\right)$ reveals the Sokoto basin aquifers generally contains good quality groundwater of Holocene age (100 to 10,000 years BP).
\end{abstract}

Keywords: stable isotopes, geochemical characterization, groundwater, Sokoto Basin.

\section{INTRODUCTION}

Northwestern Nigeria is a region with great potential for future large-scale economic development due to warm temperatures and bountiful resources; including thermal energy, farmlands and minerals. Water resources data in this area, as far back as the $60 \mathrm{~s}$, are available in literature (du Preez and Barber 1965, Ogilbee and Anderson 1965, FAO 1969, MWWR 1965-1970, FMWR 1999).

However, water, being the primary restrictive factor of economic development and exploitation of land and other resources, makes continuous evaluation of water resources important in a semi-arid region like the Sokoto Basin. Moreover, infrequent and short period of rainfall ( $<60$ raining days) in most part of the basin prevents the development of agriculture, restricting crop production to only one planting season per year. Because of the semi-arid nature of most parts of the terrain, this area suffered heavily during the last Sahelian drought (19721974). Furthermore, the encroachment of desert condition by one kilometre yearly into northern Nigeria threatens agriculture. It is in the light of this that the Federal government of Nigeria under a joint project with the International Atomic and Energy Agency, Vienna has planned a number of irrigation schemes in order to increase agricultural activities in the area to two planting seasons, thereby boosting food production.

In the Sokoto Basin, water resources can be divided into precipitation, surface water and groundwater. Prominent surface waters are the rivers Rima and Sokoto, joining close to Sokoto town, draining into river Niger and ultimately into the Atlantic Ocean. Intensive, small scale and low-cost farming is practiced in the area, yet the impacts of the irrigation activities and the application of agro-chemicals on the quality on ground or surface water are not yet fully known. The overall aim of this study is to evaluate and characterize water resources in the basin in terms of quality as well as quantity to aid in it's planning and management to meet the demands of the growing population in this area. 
Isotope and Geochemical Characterization of Surface and

Subsurface Waters in the Semi-arid Sokoto Basin, Nigeria.

\section{DESCRIPTION OF THE STUDY AREA}

\section{Physiography}

The Iullemmeden Basin of West Africa covering an estimated area of $700,000 \mathrm{~km}^{2}(\mathrm{Kogbe}, 1989)$ extends into northwestern Nigeria where it is referred to as the "Sokoto Basin".

The Sokoto Basin lies in the sub-Saharan Sudan belt of West Africa in zone of Savanna-type vegetation generally classified as semi-arid. It lies between latitudes $10^{\circ}$ and $14^{\circ} \mathrm{N}$ and longitudes $3^{\circ}$ and $7^{\circ} \mathrm{E}$ and covering an area of about 65,000 square kilometres (Fig.1). The area is bounded on the north and west by Niger Republic and on the southwest by Benin Republic. Although the Sokoto Basin of Nigeria appears extensive in area extent, it only represents about one-tenth of the entire Iullemmeden Basin of West Africa (Greigert 1961). The basin broadly covers an area underlain predominantly by crystalline rocks to the east and sedimentary terrain to the northwestern half. Most of the samples discussed in this publication are within the Sokoto sedimentary Basin in the northwestern corner of northern Nigeria (see fig.1).

Geomorphologically, the area is mainly undulating, only with depressions caused by wadis and watercourses (rivers Rima and Sokoto). The elevation of the ground is between 250 and 350 metres above sea level. Resistant crusts of laterites and ironstones characteristically cap the hills in this area. The River Sokoto-River Rima system represents the principal drainage network in this region. Other rivers like Zamfara, Gulbin Ka, and Gagere are the main tributaries.

\section{Climate}

The Sokoto Basin, in northwestern Nigeria, is a semi-arid region marked by distinct weather conditions-the wet and dry seasons. Within the Sokoto basin there is considerable variation in rainfall distribution with mean annual rainfall (over a period of 90 years) ranging from $350 \mathrm{~mm}$ at Kurdula in the extreme northwest and $670 \mathrm{~mm}$ (at Sokoto Airport). The rainy season, which usually starts from May or June of each year, lasts till September or early October depending on the rainfall pattern for that year. The average annual rainfall during this season (from 1916-2000) at Sokoto is presented as figure 2, usually with July and August as the months of heavy downpours. Between November and March is the dry harmattan period, which is completely without rain, but dust-laden and cold winds blow in from the northwest. The departure of harmattan and the onset of rain are usually marked by a hot sunny season having temperature range of $37-40{ }^{\circ} \mathrm{C}$ with the highest temperature in April. Diurnal temperature varies from $21-27^{\circ} \mathrm{C}$ and class A evaporation ranges from $<2000 \mathrm{~mm} / \mathrm{a}$ to $2500 \mathrm{~mm} / \mathrm{a}$ in the extreme north (UNESCO, 1978) with potential evapotranspiration far exceeding precipitation (see Fig. 2). As rainfall is concentrated within 3-5 months, a periodic, short-lived but strong surface runoff exists; resulting in high stream discharge. Generally, the advancement of the desert southwards that is accompanying natural climatic fluctuations both make the whole of the savanna belt subject to aridity (Fagoyinbo, 1990).

\section{GEOLOGICAL AND HYDROGEOLOGICAL SETTING}

Basement rocks dominate about $50 \%$ of Nigeria's surface area while Cretaceous and Cenozoic sediments cover the other $50 \%$. In the southeastern sector of the Iullemmeden Basin, i.e. Sokoto Basin, up to 2000 meters of clastic sequences rests upon the Basement (Zboril 1984). Moreover, in the Sokoto basin sequences of semiconsolidated gravels, sands, clay, some limestone and ironstone are found. According to Kogbe (1989) the sedimentary sequences are sub-divided from bottom to top into the late Jurassic to early Cretaceous Illo \& Gundumi Formations ("Continental Intercalaire"), the Maestrichtian Rima Group (sub-divided into Taloka, Dukamaje and Wurno Formations), the late Paleocene Sokoto Group (sub-divided into Dange, Kalambaina and Gamba Formations) and the Eocene-Miocene Gwandu Formation (fig.3). Overlying all the formations is a laterite cap usually up to 12 metres thick in some localities yielding water to most dugwells in the area.

The analysis of pumping tests data carried out in the shallow aquifer yielded transmissivities in the range of 200 to $5000 \mathrm{~m}^{2} / \mathrm{d}$ and storage coefficients of $10^{-2}$ to $10^{-5}$ indicating semi-unconfined to confined conditions (Bassey et al., 1999). Based on these, the hydraulic conductivity varies between $10^{-4}$ to $>10^{-3} \mathrm{~m} / \mathrm{sec}$. The yield of tubewells up to 20 meters depth is generally $>2 \mathrm{~L} /$ sec. The fluctuation of the water table in the fadama area is about 2-3 meters throughout the year. The water table is lowest in June and highest in September at the end of the raining season. As precipitation in the area is concentrated within 3-5 months a periodic, short-lived but strong surface runoff results.

The headwaters of the rivers Sokoto and Rima as well as their tributaries take off from the pre-Cretaceous crystalline basement terrain east of the basin and flows west and south. Stream discharge has been measured on 


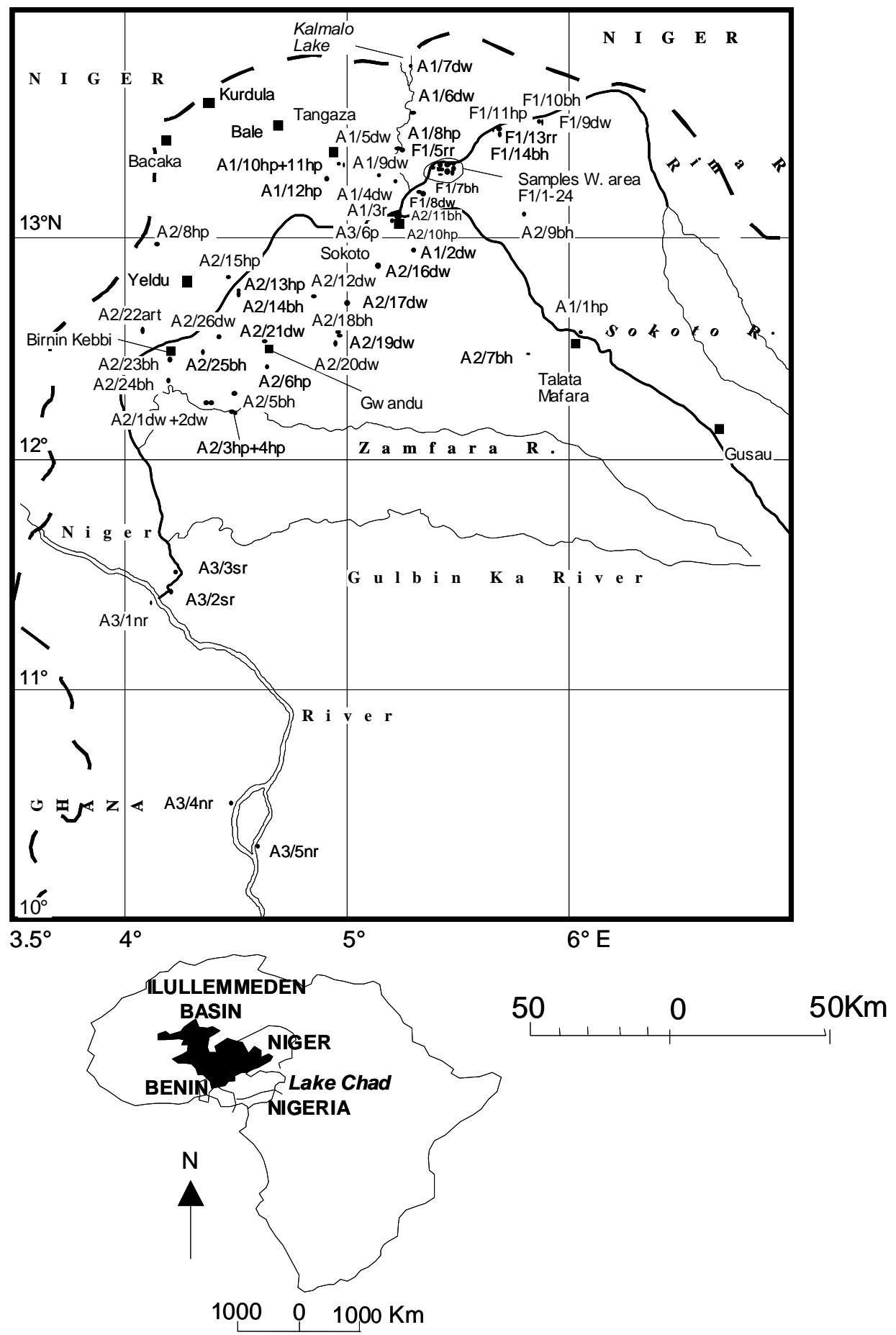

Figure 1: Map of study area with sampling locations and sample numbers (Below-Map of Africa showing the Iullemmeden Basin of West Africa in dark shade) 


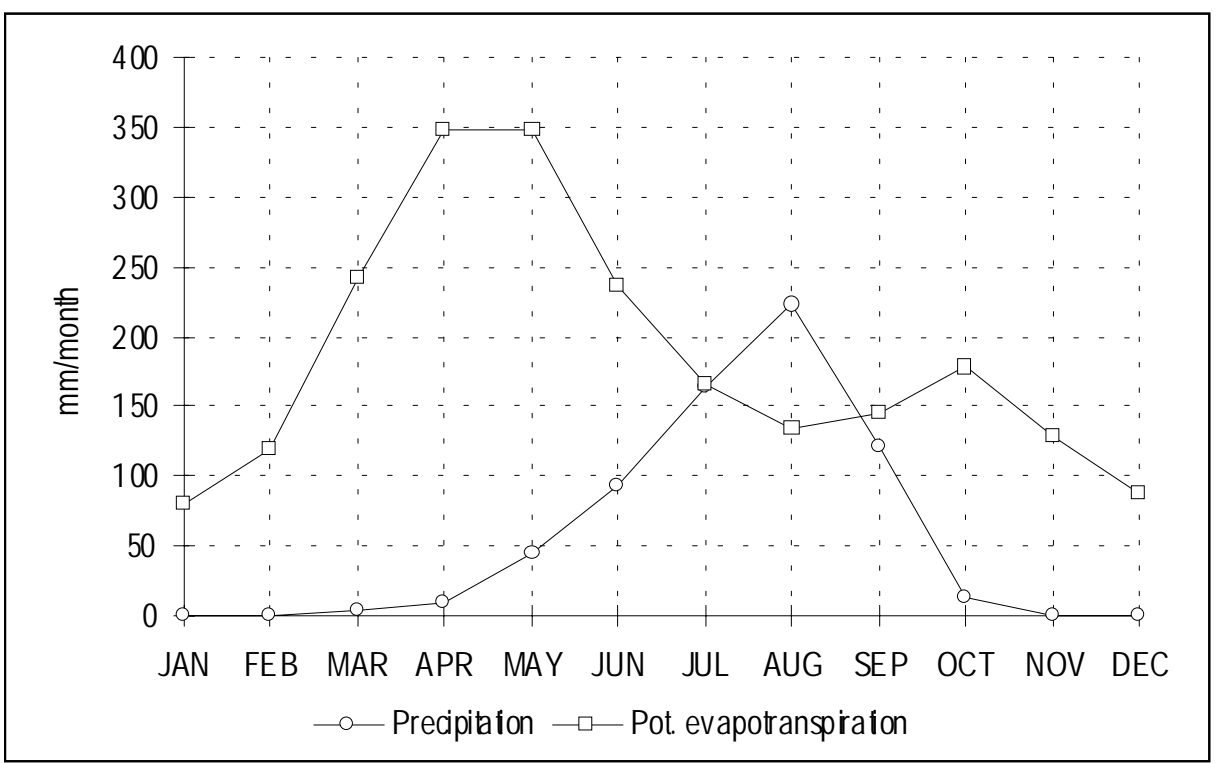

Figure 2: Mean monthly precipitation and potential evapotranspiration.

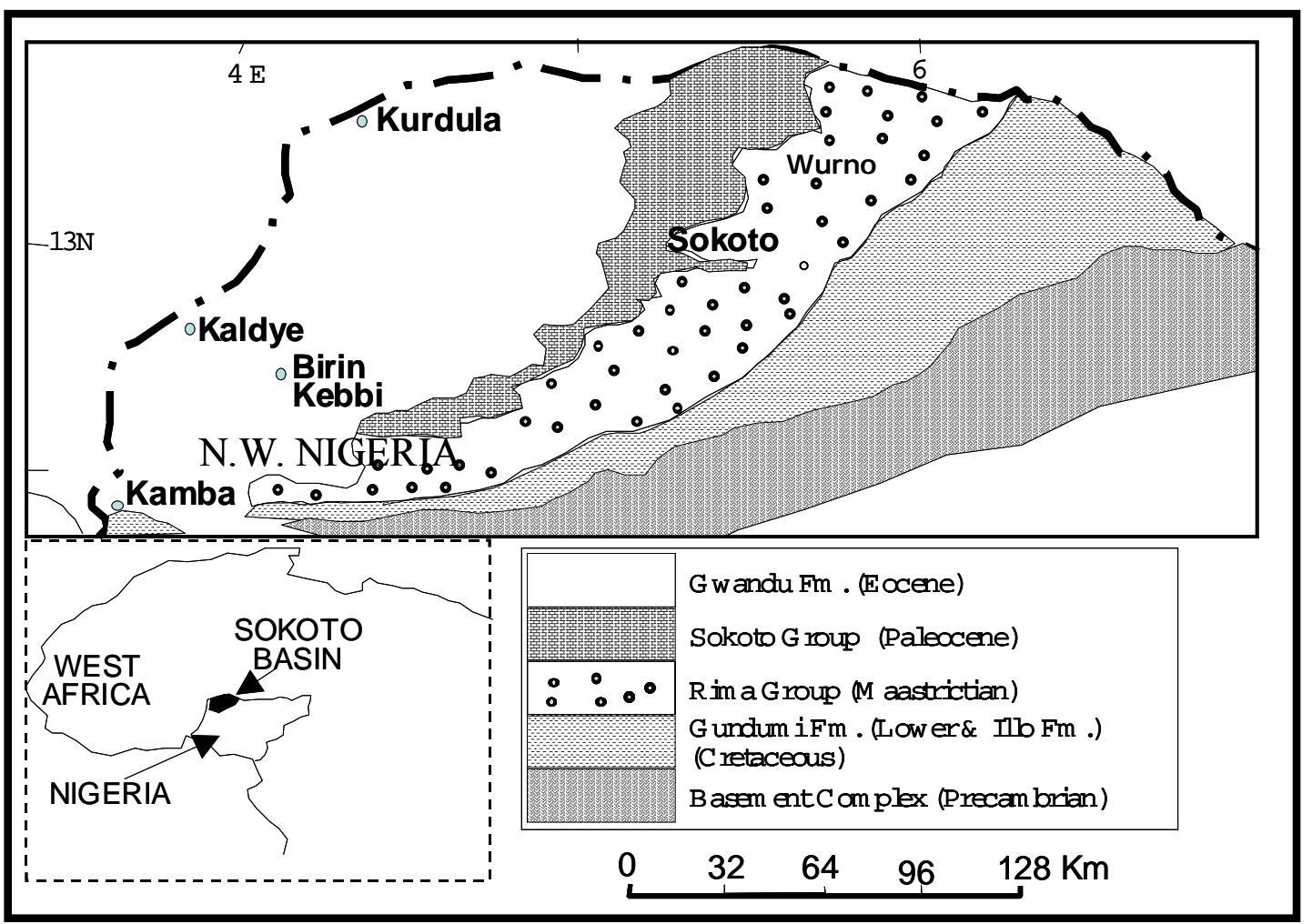

Figure3: Geological map of Sokoto sedimentary basin, NW Nigeria (Modified from Oteze, 1991) 
daily basis at 26 gauging stations on the Sokoto-Rima drainage basin (Anderson \& Ogilbee, 1973). For example, $7.13 \times 10^{9} \mathrm{~m}^{3} / \mathrm{a}$ of discharge was recorded at Gidan Donka, $9.64 \times 10^{8} \mathrm{~m}^{3} / \mathrm{a}$ at Sabon Birni and $1.63 \times 10^{9} \mathrm{~m}^{3} / \mathrm{a}$ at Wamako, southwest of Sokoto town. Figure 4 shows the hydrograph of monthly runoff of river Sokoto at Wamako. Rainfall is directly responsible for stream discharge in these areas; the groundwater contribution to stream flow is usually small. Due to the sporadic nature of rainfall and fast surface run-offs infiltration into the groundwater system is drastically reduced. However, between Sabon
Birni (about $70 \mathrm{~km} \mathrm{NE}$ of Rabah village) and Sokoto town the Rima river looses about $5.07 \times 10^{7} \mathrm{~m}^{3}$ of water to the ground every year (Oteze 1989a). Artesian aquifers occur at depth in the Gundumi Formation, the Rima Group, and the Gwandu Formation. A perched groundwater body occurs locally at shallow depth in the limestone of the Kalambaina Formation. This aquifer sustains numerous dugwells, springs and ponds (Anderson \& Ogilbee 1973), some of which were sampled in this study.

\section{METHOD OF INVESTIGATIONS}

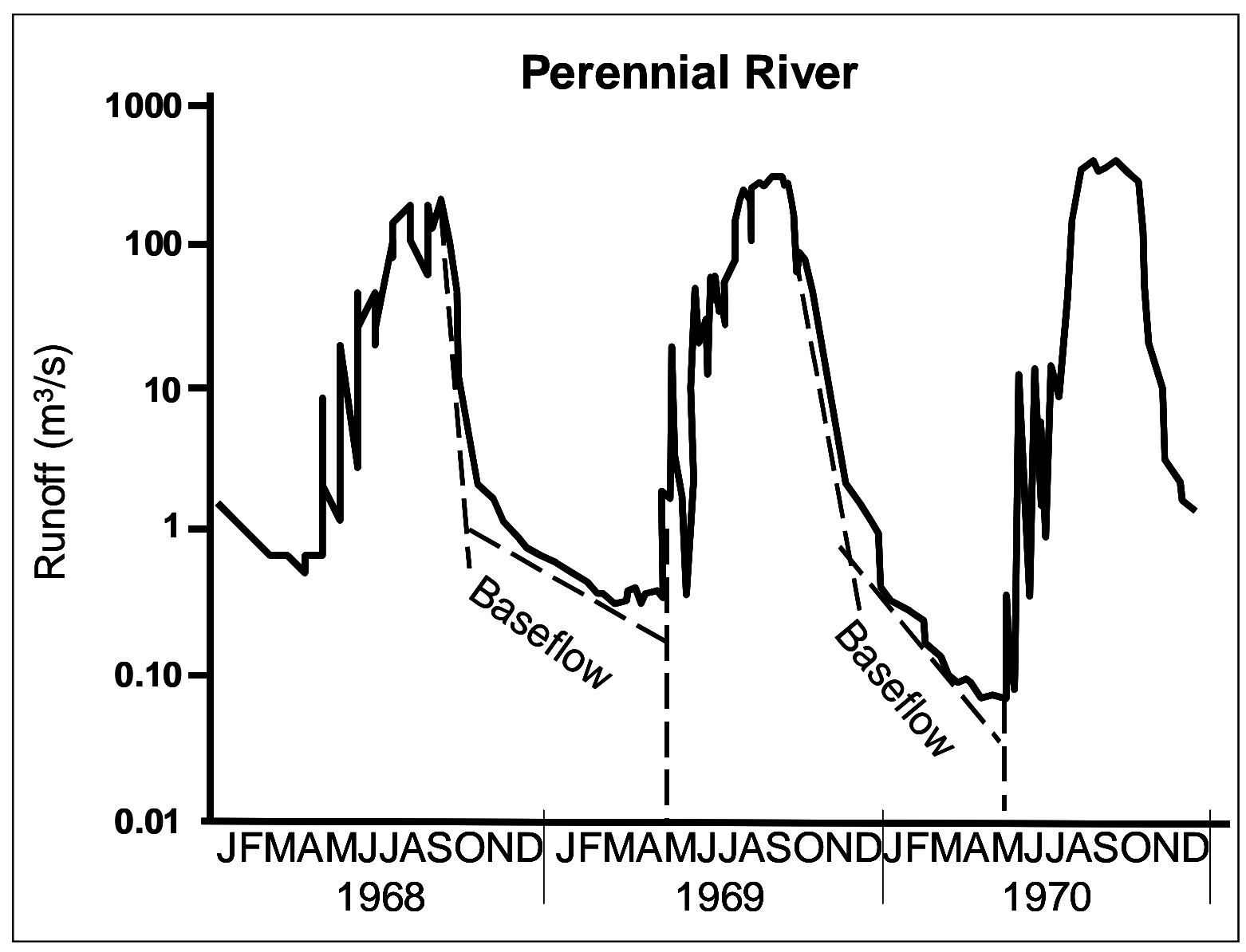

Figure 4: Hydrograph of monthly runoff of river Sokoto at Wamako (Modified from Anderson and Ogilbee, 1973) 
Isotope and Geochemical Characterization of Surface and

Subsurface Waters in the Semi-arid Sokoto Basin, Nigeria.

In order to achieve the aim of the present study more than 190 samples were taken so far from dugwells and tubewells, boreholes, lake as well as rivers Rima and Sokoto in four major sampling campaigns under the Federal Ministry of Water resources (Nigeria) and three fieldworks under the University of Ilorin (Nigeria) in collaboration with Technical University, Darmstadt (Germany). As a reference to ground water 10 rainwater samples were collected from 3 different stations (Goronyo, Wurno and Sokoto) for isotope analyses. Physical parameters like temperature, $\mathrm{pH}$, electrical conductivity (EC), dissolved oxygen and alkalinity were measured in the field using potable meters and "Aqua Merck" titration kits. Water samples were collected in airtight bottles (avoiding bubbles while sampling) for further laboratory analyses. The hand-dug wells were sampled using drawing buckets tied with a rope while the hand pump and the boreholes that were equipped with mono-/ submersible pumps were sampled after 5 minutes of pumping. Tube wells were also sampled but with surface pumps. Two $500 \mathrm{ml}$ water samples were taken from each well for chemical and isotopic analyses respectively.

Main chemical components and the environmental isotopes $\mathrm{H}-2, \mathrm{H}-3, \mathrm{C}-13, \mathrm{C}-14$ and $\mathrm{O}-18$ have been analyzed. With respect to $\mathrm{C}-13$ and $\mathrm{C}-14$ only few samples have been taken. Chemical analyses were carried out in the laboratories of national Water resources Institute, Kaduna (Nigeria) and Institute of Geosciences, Technical University Darmstadt (Germany). Analyses of the stable and radioisotopes were jointly analyzed at the Schonland
Research Center, University of Witwatersrand, Johannesburg, South Africa, the Middle Eastern Regional Radioisotope Center, Cairo, Egypt and Hydroisotop $\mathrm{GmbH}$, ScweiterKirchen, Germany. Stable isotopes ratios are expressed as delta in per mil $(\delta \%$ ) relative to VSMOW (Vienna Standard Mean Ocean Water). The isotope precision of measurement based on VSMOW is $\pm 0.15 \%$ o for ${ }^{18} \mathrm{O}$ and $\pm 1 \%$ for ${ }^{2} \mathrm{H}$. The study is part of a technical cooperation project between the International Atomic Energy Agency, Vienna, Technical University Darmstadt, Germany, Federal Ministry of Water Resources and University of Ilorin in Nigeria.

\section{RESULTS AND DISCUSSION}

Results of field analysis of the water samples have shown a $\mathrm{pH}$ range of $5.5-8.3$; electrical conductivity of $45-1$, $155 \mu \mathrm{S} / \mathrm{cm}$ and total dissolved solids (TDS) of between 16 to $1,063 \mathrm{mg} / \mathrm{l}$. For the classification of groundwater in the study area, the major ions sodium, potassium, calcium, magnesium, chloride, bicarbonate, sulphate and nitrate were analyzed. Even the anions phosphate and fluoride were measured in some places. The dominant anion is bicarbonate although places of significant concentration of sulphate were recorded depending on where the sample was taken. It is generally difficult to find any significant criterion in the chemical solutions of groundwater for distinction of the different aquifer types. However, five groups of water samples were formed to plot the equivalent concentration of the major ions and ionic combinations (fig. 5). These groups, with their distinguishing chemical composition, are as follows: (I) deep groundwater from boreholes $\left(\mathrm{HCO}_{3}>\mathrm{SO}_{4}>\mathrm{Cl}\right)$,

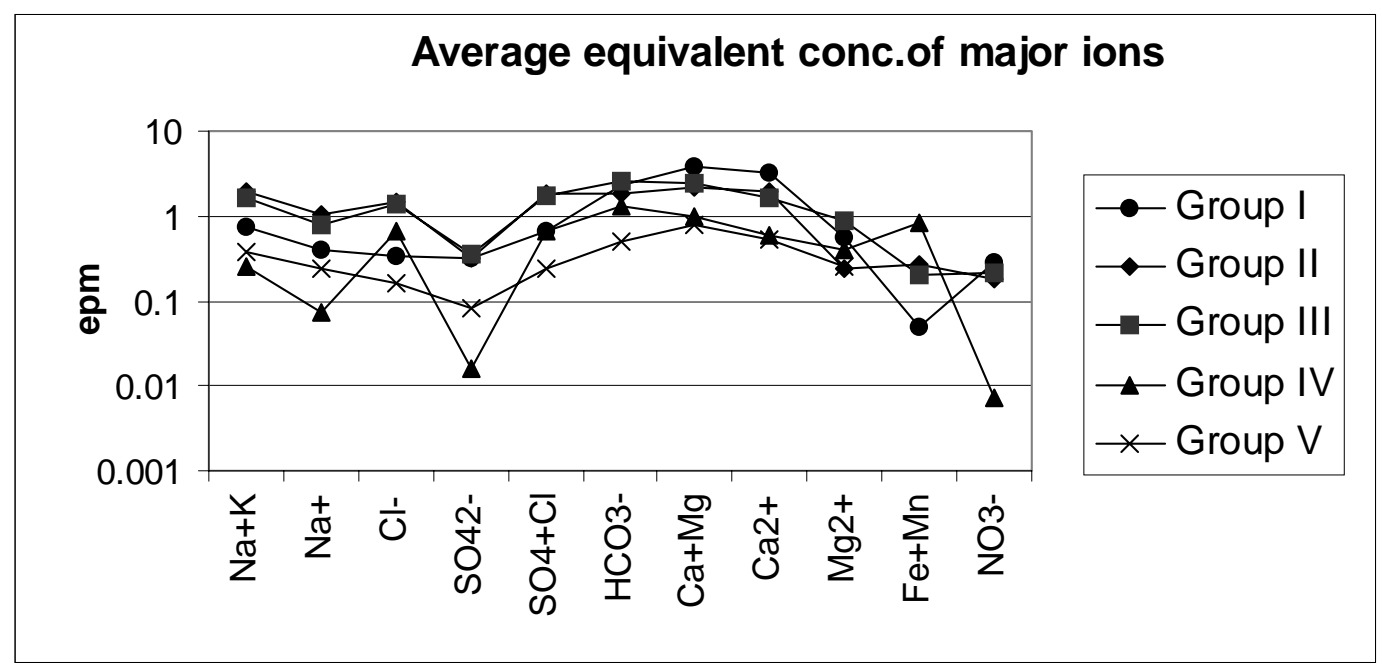

Figure 5: Schoeller diagram for groups I - V 
(II) shallow groundwater mainly from dug wells outside the irrigation area $\left(\mathrm{SO}_{4}>\mathrm{HCO}_{3}>\mathrm{Cl}\right)$, (III) shallower groundwater from tube wells and some dugwells around the Wurno Irrigation Scheme, $\left(\mathrm{Cl}>\mathrm{HCO}_{3}>\mathrm{SO}_{4}\right)$, (IV) Lake and Carnal waters $\left(\mathrm{HCO}_{3}>\mathrm{Cl}>\mathrm{SO}_{4}\right),(\mathrm{V})$ Rivers Rima and Sokoto $\left(\mathrm{HCO}_{3}>\mathrm{SO}_{4}>\mathrm{Cl}\right)$.

The average equivalent concentration of major ions and ionic combinations clearly show the relationship of these groups. In these five groups, average concentrations between selected ions and ionic combinations respectively occur more or less in the same ratio. However, the absolute ionic concentration differs significantly between the groups. For example, Groups IV and V show all together the lowest ionic concentration. Above all, the concentration of alkali-earth elements in these two groups is extremely low compared to the other groups. The ratio between alkali and earth-alkali elements allows the distinction of the groups II, III, and I whereas the ratio between calcium and magnesium indicates no significant differences. From the figure 6 it is obvious that the water groups are fairly parallel one to the other. The fairly parallel lines of each group and with the parallelism of each water group line to other group lines, an indication of common origin, is obvious for all of the waters in the study area. Numerous Chemical and physical reactions and interaction of the percolating rainwater with underlying rocks have been interpreted as producing the groups. However, these water groups can by mixing or concentration evolve into each other systematically.

Generally, the characteristic hydrochemical classification in the study area (based on chemical composition of the water samples) is the calcium-alkali-bicarbonate type. Surface waters are characterized by alkali-calciumbicarbonate while groundwater is of $\mathrm{Ca}-\mathrm{Mg}-\mathrm{HCO}_{3}$ (except around Karibi, Tangaza and Balle, all northwest of Sokoto town where $\mathrm{Ca}(\mathrm{Mg})-\mathrm{SO}_{4}$ type predominates). In these areas, a locally elevated content of sulphate exists, where 119, 215 and $451 \mathrm{mg} / \mathrm{L}$ were recorded respectively as compared to $<50 \mathrm{mg} / \mathrm{L}$ that characterized other areas. The high concentration of sulphate recorded in this area may have resulted from the dissolution of gypsum (which is fairly abundant in the area) in an atmosphere that hold iron in high concentration and high $\mathrm{pH}$ other than the oxidation of pyrites which is usually accompanied by low $\mathrm{pH}$. This is confirmed by the high $\mathrm{pH}$ in these locations (7.9, 8.1 and 8.3 respectively). This observation also agrees with the geochemical measurements in the past, when up to $643 \mathrm{mg} / \mathrm{L}$ of sulphate ion was recorded at Kware (close to Tangaza) by Oteze (1991).
The study of stable isotope contents $\left({ }^{18} \mathrm{O},{ }^{2} \mathrm{H}\right)$ also identified the five groups (Fig. 6). Group I-III is of groundwater origin while group IV and V represent surface water. It is obvious that, between the deeper groundwater (group I) and the overlying water bodies, no transition zones are known, as they can be clearly separated. For the shallower groundwater, however, admixtures of groups II, III, with groups IV and V are obvious. Group II and III stem mainly from direct recharge by precipitation. However, due to lack of sufficient information on the position of the screens, the depth penetration of recharging water is not known.

Except few samples of shallow and surface water which defined a local evaporation line of slope 5.1, no signification evaporation was found to occur during infiltration; most of the points plot close to the Global Meteoric Water Line (GMWL) and the weighted mean of precipitation in Kano (Onugba et al, 1990). The rainwater sampled from 3 different locations (Sokoto, Goronyo and Wurno) during the summer season of 1999 has been included in this plot. Rainwater samples from these three localities were distinguished in the plot as W/8/99, signifying sample from Wurno August 1999 rain; G/7/99, Goronyo July 1999 rain and S/6/99 as Sokoto June 1999 rainwater. The precipitation of June, July and August has a large range showing an unusual strong depletion (median of $\delta \mathrm{D}$ at-40\%o) as compared with groups II, III, IV.

This phenomenon has been attributed to the heavy downpours during this period and is supported by the high tritium values observed in wells with depth less than 15 $\mathrm{m}$ below ground surface. This is especially the case with the samples collected from tube wells and dugwells around the Wurno Irrigation Scheme area (i.e. samples F1/1-24). For example dug wells at Gidan Ali (around the Wurno Irrigation Scheme), Dandere valley ( $4 \mathrm{~km}$ from Wurno town), and Lemu village ( $25 \mathrm{~km}$ from Wurno) have tritium values of $17 \mathrm{TU}, 18 \mathrm{TU}$ and $15.3 \mathrm{TU}$ respectively. The corresponding well depths are respectively $9.8,11.5$, and $2.87 \mathrm{~m}$. In contrast, wells tapping groundwater at relatively deeper levels (i.e. $>20 \mathrm{~m}$ below the surface) were observed to be much depleted in tritium with a range of 0.3 to 0.6 TU. However, there is a significant deviation of the deuterium excess parameters (i.e. -26.04 to $8.24 \%$ ) from the global average particularly for the samples collected during the dry season when there was little or no rainfall. This confirm that groundwater in the shallow aquifers of the study area are recharged by rain or running river water.

The groundwater samples from selected wells (deep 


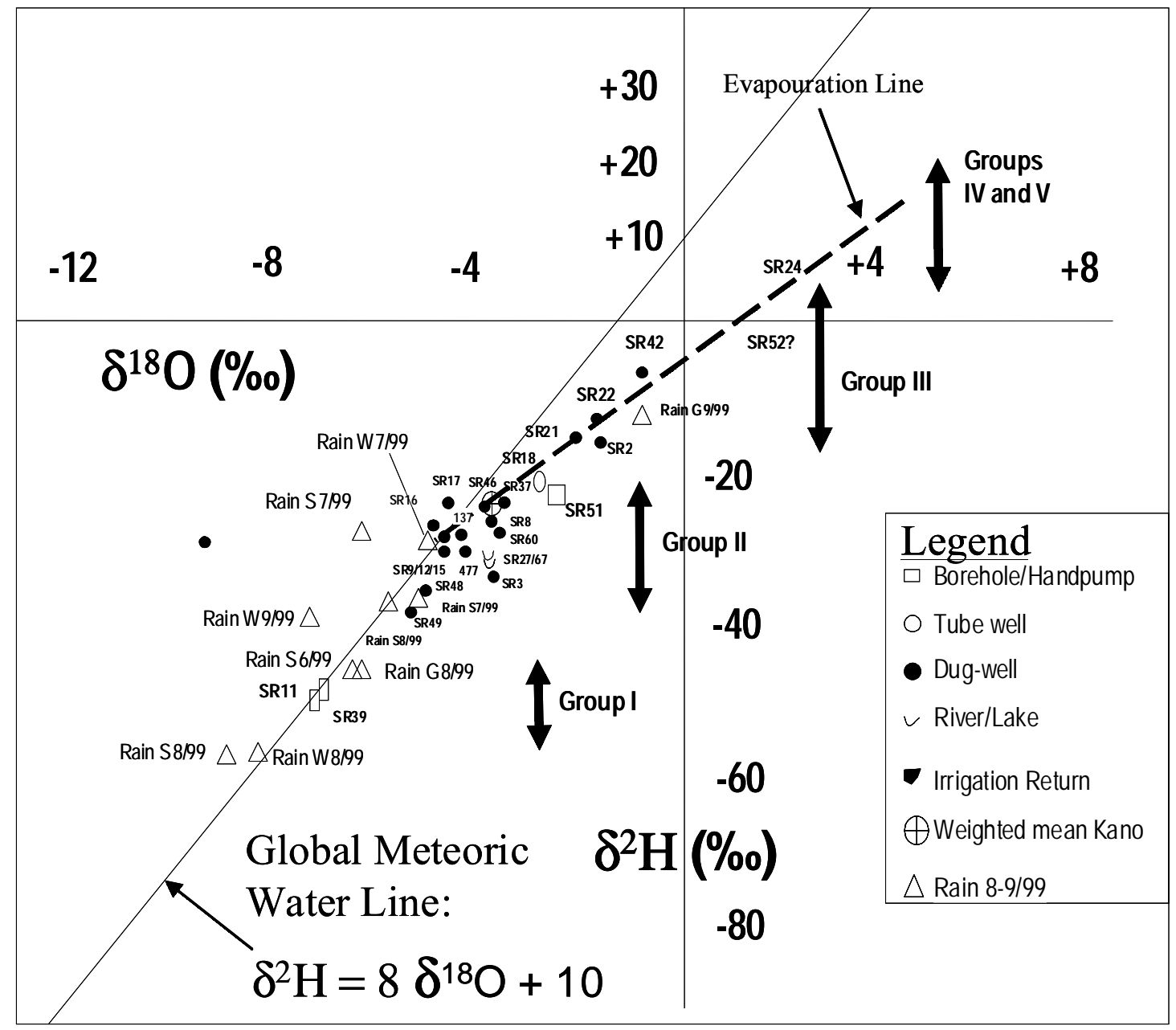

Figure 6: Relationship between $\delta^{2} \mathrm{H}$ and $\delta^{18} \mathrm{O}$ in groundwater and surface water

boreholes with an average static water level of $50 \mathrm{~m}$ below ground level) were dated by the ${ }^{14} \mathrm{C}$ method. It is possible to get a measure of the age of groundwater using the present ${ }^{14} \mathrm{C}$ content of the sample in comparison with the initial ${ }^{14} \mathrm{C}$ content, provided it has had no contact with the atmosphere during the time of its movement within the aquifer. This dating was restricted to the Rima Group (Taloka Formation) aquifer, especially around the Wurno and Goronyo Irrigation Schemes. Results of ${ }^{14} \mathrm{C}$ in 7 groundwater samples from deep boreholes range from 14.7 to $30.0 \mathrm{pMC}$ with a corresponding calculated agerange of 9,670 to $15,380 \pm 80$ years B.P. This presupposes the groundwater of this aquifer to be essentially paleowaters, almost ruling out rain recharge. The values of stable ${ }^{13} \mathrm{C}$ isotopes in the same 7 samples range from -16.27 to $-9.04 \%$ PDB. These have helped to correct the ${ }^{14} \mathrm{C}$ ages slightly. Due to the generally low mineral content of the samples in the present study area, it is not likely that the ${ }^{14} \mathrm{C}$ ages have been changed by chemical reactions in the aquifers of the basin. From the geological evidence available in the catchment area an initial ${ }^{14} \mathrm{C}$ content of 85 per cent modern carbon or more may be assumed (Geyh 1972). Using this assumption the conventional ${ }^{14} \mathrm{C}$ ages may exceed the actual groundwater ages by 3000 to 4000 years (Adelana et al. 2001). 
Earlier age determinations (by ${ }^{14} \mathrm{C}$ ) for groundwater from other aquifers in the Sokoto Basin have been reported in literature (Oteze 1989b, Geyh and Wirth 1980). Oteze reported the ${ }^{14} \mathrm{C}$ age for groundwater of the Rima group (Wurno Formation) aquifer as 19,000 years at Birnin Kebbi and 26,000 years old at Kaloye. However, conventional ${ }^{14} \mathrm{C}$ ages from 3,000 (at Tangaza) to 30,000 (at Yeldu) years B.P. were determined for groundwater of the confined Gwandu Formation aquifers (Geyh and Wirth 1980).

The absence of tritium or low tritium values $(0-4 \mathrm{TU}$, average of $1.66 \mathrm{TU}$ in 36 deep wells) confirms the samples do not contain recently recharged groundwater. These tritium concentrations of groundwater samples in the study area are indicative of older waters at depth. Relatively higher tritium values in both surface and shallower wells $(<15 \mathrm{~m})$ contrary to the groundwater samples obviously indicate that the rivers are merely surface runoffs/rainwater formed after 1952. The clear difference shows that the deep aquifers in this area do not recharge the rivers (as discussed in the preliminary studies, Adelana et al. 1999, Olasehinde et al. 2001) but rather indicate varying mean resident time. The details of aquifer recharge in the Sokoto sedimentary basin have been discussed in Adelana et al. (2002).

\section{SUMMARY AND CONCLUSION}

A use has been made of isotopes and hydrochemical data to characterize water resources in the Sokoto basin, which represents the southeastern sector of the Iullemmeden basin of West Africa. The plots of the data have shown distinct water groups from both surface and groundwater. Hydrochemical character reveals groundwaters are of Ca$\mathrm{Mg}-\mathrm{HCO}_{3}$ while surface waters (rain and rivers) are characterized by alkali-calcium-bicarbonate. A plot of isotopic composition shows five water groups can be distinguished. Group I-III are of groundwater origin while group IV and V represent surface water. A combination of the hydrochemical and isotope data $\left({ }^{14} \mathrm{C},{ }^{13} \mathrm{C}\right.$ and $\left.{ }^{3} \mathrm{H}\right)$ reveals the Sokoto basin aquifers generally contains good quality groundwater of Holocene age (100 to 10,000 years Bp).

The isotopic data have further given useful information on the varying age of groundwater and recharge mechanism in the study area. However, the age determination of aquifers in the Sokoto Basin require further research as the data used for the dating exercise in this work and previous works were few. More accurate groundwater dating could be obtained with more data and the use of other dating methods that have proved useful in recent time.

\section{REFERENCES}

Adelana, S.M.A.; Olasehinde, P.I. and Vrbka, P. "Groundwater recharge in the Cretaceous and Tertiary sediment aquifers of northwestern Nigeria, using hydrochemical and isotopic techniques". In: Bocanegra E., Martinez D and Massone H. (eds) Groundwater and Human Development, Mar de Plata, Argentina, pp.907 - 915, October 2002.

Adelana, S.M.A.; Olasehinde, P.I. and Vrbka, P. "Hydrogeological investigation in the Sokoto basin using environmental isotopes" Water Resources, 12(1\&2), pp.14-21, 2001.

Adelana SMA, Olasehinde PI, Vrbka, P, and Esan A. "A note on the results of isotope study of wells in the Sokoto sedimentary basin, northwestern Nigeria" Water Resources, 10 (1\&2), pp. 13-18, 1999.

Anderson, H.R \& Ogilbee, W., "Aquifers in the Sokoto Basin” Geol. Survey Water Supply paper 1757-L, USGS Report, 79p, 1973.

Bassey, J.O.; Maduabuchi, C.; Onugba, A.; Verhagen, B.Th. \& Vrbka, P., "Preliminary results of hydrogeological and isotopic research in the Rima River Basin, NW Nigeria" Water Resources 10 (1\&2), 31-37, 1999.

du Preez, J.W. and Barber, W., "The distribution and chemical quality of groundwater in Northern Nigeria" Geological Survey of Nigeria Bull. 36, p.38-45, 1965.

Food and Agricultural Organisation (FAO) "Soil and water resources survey of Sokoto valley, Nigeria" Climate and Hydrology, Vol. IV, 85p, 1969.

Geological Survey of Nigeria (GSN) Geological map of Nigeria series 1:250,000, sheet Nos. 1,2,3,6,7, and 8, GSN 1964.

Geyh, M.A. "Basic studies in hydrology and $14 \mathrm{C}$ and $3 \mathrm{H}$ measurements" Proc. 24 ${ }^{\text {th }}$ Int. Geol. Congr., Montreal, Quebec, 11: 227-234, 1972.

Geyh, M.A. \& Wirth, K. "14C ages of confined groundwater from the Gwandu aquifer, Sokoto basin, Northern Nigeria" Journal of hydrol. 48: 281-288, 1980.

Greigert, J. "Carte geologique de reconnaissance du Bassin de Iullemmeden: Republique du Niger “ Direction Federale de Mines, scale 1:1,000,000, 1961.

Kogbe, C.A., "Cretaceous and Tertiary of the Iullemmeden Basin in Nigeria" In: C.A. Kogbe (eds.), Geology of Nigeria, 377-421. Jos, Rock View Publ. Co., 1989.

Ministry of Works and Water Resources (MWWR), Northern Nigeria and FAO Hydrological Year Book 1965-1970: April 1965- March 1966, April 1966March 1967, April 1967- March 1968, April 1968March 1969, April 1969- March 1970. 
Federal Ministry of Water Resources (FMWR) Meteorological and Hydrological Year Book, Federal Ministry of Water Resources, Abuja, Nigeria, 1999.

Olasehinde PI, Vrbka, P. and Adelana SMA "The Isotopic and Hydrochemical framework of the groundwater system within the Nigerian sector of the Iullemmeden Basin, West Africa"- African Journal of Science and Technology, Science \& Engineering Series Vol.1, No.4, Pp.43 - 50, UNESCO Publication, 2001.

Oteze, G.E., "Potability of Groundwater from the Rima Group Aquifers in the Sokoto Basin, Nigeria" Journal of Min. Geol. 27(1), 17-23, 1991.

Oteze, G.E., "The hydrogeology of nortwestern Nigeria" In: C.A. Kogbe (eds.), Geology of Nigeria, 455472. Jos, Rock View Publ. Co., 1989a.
Oteze, G.E. "Environmental Isotope Hydrology of the main Rima Aquifer Waters" - Jour. Min. Geol., 25 (1\&2), pp.205-210, 1989b.

Onugba, A.; Blavoux, B. \& Dray, M., "The environmental isotopes in monthly precipitation at Kano (Nigeria) from 1961-1973" In: Proc. $1^{\text {st }}$ Biennial National Hydrology Symposium, Maiduguri, 67-88, UNESCO, 1990.

United Nations Educational, Scientific and Cultural Organization (UNESCO), "World Water Balance and Water Resources of the earth, UNESCO, 663p, 1978.

Zboril, L. "Sketch map of oil-bearing structures" Geofyzika, Brno, Czechoslovakia, 94p, 1984. 